\title{
A 400 METER DEEP ICE GORE IN GREENLAND
}

\author{
PRELIMINARY REPORT
}

\author{
By Chester C. Langway, Jr.
}

(Snow and Ice Basic Research Branch, Snow Ice and Permafrost Research Establishment, Corps of Engineers, U.S. Army, Wilmette, Illinois, U.S.A.)

As part of the 1956 and 1957 summer research programs conducted on the Greenland Ice Cap by the U.S. Army Snow Ice and Permafrost Research Establishment, Corps of Engineers, a deep rotary core-drilling program was instituted to develop techniques to be used in the Antarctic International Geophysical Year activities. The drill site was located in northwest Greenland approximately 200 miles $(320 \mathrm{~km}$.) east of Thule, at an elevation of $7000 \mathrm{ft}$. $(2 \mathrm{r} 34 \mathrm{~m}$.). This is a dry snow zone and the mean annual accumulation is equivalent to $40 \mathrm{~cm}$. of water. The mean annual surface temperature is $-25^{\circ} \mathrm{C}$.

With the development of these drilling techniques, deep ice cores became available for investigation for the first time and present a unique opportunity to study the physical and chemical nature of high-polar glacier ice in a nearly continuous profile of over $400 \mathrm{~m}$.

In 1956 , the first year of the tests, over 50 per cent of the core was recovered to a depth of over $300 \mathrm{~m}$. A new hole was drilled to $4 \mathrm{I} \mathrm{m}$. in 1957 . Core recovery was almost continuous down to $300 \mathrm{~m}$.; the remainder consisted of two 6-meter lengths, the deepest from $400 \mathrm{~m}$.; the capacity of the drilling rig prevented further penetration. Cooled compressed air was used to blow out cuttings, and there was no indication of collapse in the hole.

The core was passed over a light table to assist in determining the stratigraphy. It was then cut into various lengths, depending upon the observed stratigraphic features, and densities were determined.

The pieces of core are $10 \mathrm{~cm}$. in diameter and vary in length from ${ }_{1} 5$ to $45 \mathrm{~cm}$. The entire core was sawed in half lengthwise for insurance against total loss during shipment. One half of the 1957 core remains in storage, together with the 1956 core, in a covered snow trench at the drilling site. One hundred and sixty meters of selected half-core was flown in dry ice to the SIPRE laboratory at Wilmette for further detailed investigation. Half a dozen thin sections were studied in the laboratory at the drilling site, and are being remeasured at Wilmette in order to detect any structural changes that may take place during transportation and storage.

We have now begun a detailed study of the core for stratigraphy (exact dating, annual accumulation), pressure in the enclosed air bubbles, shape and size distribution of the bubbles, porosity and permeability, snow structure, metamorphism and ice-fabrics, particulate content, isotopic analysis (e.g. $\mathrm{O}^{16} / \mathrm{O}^{18}$, deuterium, tritium), grain size distribution, and bacteria content. The work is being done by SIPRE, other Governmental agencies and universities. Proposed studies include spectral analysis, dynamic elasticity determinations and creep studies. As studies are completed reports of the findings will be published.

Although the quantity of core is limited, some can be made available to other investigators. Interested persons are cordially invited to submit proposals for further studies.

The accompanying Fig. I on p. 216 shows the depth-density relation. The amount of scatter is small. The ice temperature decreased with depth and the temperature gradient between 250 and $400 \mathrm{~m}$. was constant at $0 \cdot 14^{\circ} \mathrm{C}$. per $100 \mathrm{~m}$. The temperature at $400 \mathrm{~m}$. was found to be $-25 \cdot 42^{\circ} \mathrm{C}$.

MS. received I 8 December 1957 